\title{
Developing Patterns of Care in Mental Illness and Mental Handicap
}

\author{
IsABel C. A. Moyes, Chairman, Nursing Committee
}

The second symposium to be arranged for nurses and psychiatrists by the Nursing Committee was held at the Quarterly Meeting of the College in London on 17 November 1983. A criticism of the initial meeting held in Liverpool in April 1982 was that although nursing attendance had been excellent, the response from the psychiatrists had been poor. This was disappointing as the aim of the meetings was to provide a forum where topics of mutual interest or concern could be freely discussed. However, on this occasion, when the Chairman of the meeting, Dr Birley, called for psychiatrists in the audience to identify themselves, out of the ninety or so present, two-thirds were psychiatrists.

Mr D. McCarthy, Director of Nursing Services for the Portsmouth Health Authority, described how a team had been built up to look after the care of long-stay patients. Clear definition of aims and policies had enabled nursing members to take responsibility and consultants to delegate authority with the minimum of friction, while the formation of small project teams enabled new developments to be researched before being put to the whole team.

Dr K. Day from Morpeth followed with an account of how the multidisciplinary team approach had been essentia in placing and maintaining patients with mental handicap in the community. He stressed, however, that it would still be necessary for severely disabled people to be in some type of hospital unit and the team needed to give support there also. There had been an unrealistic expectation in some quarters that all need for beds would disappear and that this had had to be combated. Also there might be problems in nurse training because the new syllabus tended to place less emphasis on hospital based work.
Dr Muir Gray, Community Physician from Oxford, challenged the audience to reconsider the way in which they used terms. Why should community care be seen as totally separate from hospital care? People saw services as if they were 'boxes' and a decision had to be made if a move was to be made from one 'box' to another. Much more flexibility between services was needed. He was about to initiate a pilot project of managing severely demented elderly patients in Social Services accommodation, but with NHS nursing staff also involved.

The final speaker was $\mathrm{Mr}$ A.P. Andrews, formerly lecturer in law from the South West Thames Regional Education Centre, now Senior Assistant Secretary, South East Thames RHA. He spoke on the implications for nurses and doctors of the changes in legislation contained in the Mental Health Act 1983. His effect upon the audience was not unlike the impact of a new draft of troops upon the Duke of Wellington who is said to have remarked: 'I don't know what effect these men will have upon the enemy but, by God, they terrify me!' Mr Andrews made us acutely aware of our obligations in a strictly legal sense. He put forward the salient points of the new Act as it affects our day-to-day practice. He drew nurses and doctors to a realisation of how differently from lawyers we see our duty of care and how important it is for us to understand wherein the differences lie when we may be called upon to account for our actions in court.

The meeting appeared to have been generally enjoyed by both professional groups. It was well attended and some useful suggestions were made about topics for future occasions.

\section{Post-Qualifying Courses in Alcoholism: $A$ Correction}

It is regretted that an error appeared in this notice (Bulletin, November 1983, 7, 216). The second course listed is incorrectly titled 'Postgraduate Diploma Course in Alcohol Studies'-this should have read 'Counselling Problem Drinkers Course'. The 'Alcohol Studies Course' is an 11-month course which includes in-college teaching, practice supervision and research and is run by the Alcohol Studies Centre at Paisley College of Technology. Further information is available from the Secretary at the Alcohol
Studies Centre, Westerfield Annexe, 25 High Calside, Paisley PA2 6BY, Scotland (telephone: 041-889-3225).

\section{Anuual Meeting: Short Papers Session}

It is planned to hold a session of Short Papers of original research findings at the Annual Meeting to be held in Cardiff from 11 to 13 July 1984. The Programmes and Meetings Committee has requested that submissions for this should be sent in on abstract forms. These forms are available from Miss D. Hart at the College. Completed abstract forms are to be returned by 27 April 1984 . 